\title{
A Molecular Chameleon with Fluorescein and Rhodamine Spectroscopic Behaviors
}

Ling Li, ${ }^{\ddagger a}$ Chunyan Wang, ${ }^{\ddagger a}$ Jianjian $\mathrm{Wu}^{\mathrm{b}}{ }^{\mathrm{a}}$ Yu-Chung Tse, ${ }^{\mathrm{b}}{ }^{*}$ Yue-Peng Cai ${ }^{\mathrm{c}}$ and Keith Man-Chung Wong $^{\mathrm{a} *}$

a Department of Chemistry, South University of Science and Technology of China, No. 1088, Tangchang Boulevard, Nanshan District, Shenzhen 518055, P.R. China.

E-mail: keithwongmc@sustc.edu.cn

b Shenzhen Key Laboratory of Cell Microenvironment, Department of Biology, South University of Science and Technology of China, No. 1088, Tangchang Boulevard, Nanshan District, Shenzhen 518055, P.R. China.

E-mail: tseyc@sustc.edu.cn

c School of Chemistry and Environment, South China Normal University, Guangzhou 510006, P.R. China

* C.W. and L.Li contributed equally to this work.

\section{Supporting Information}



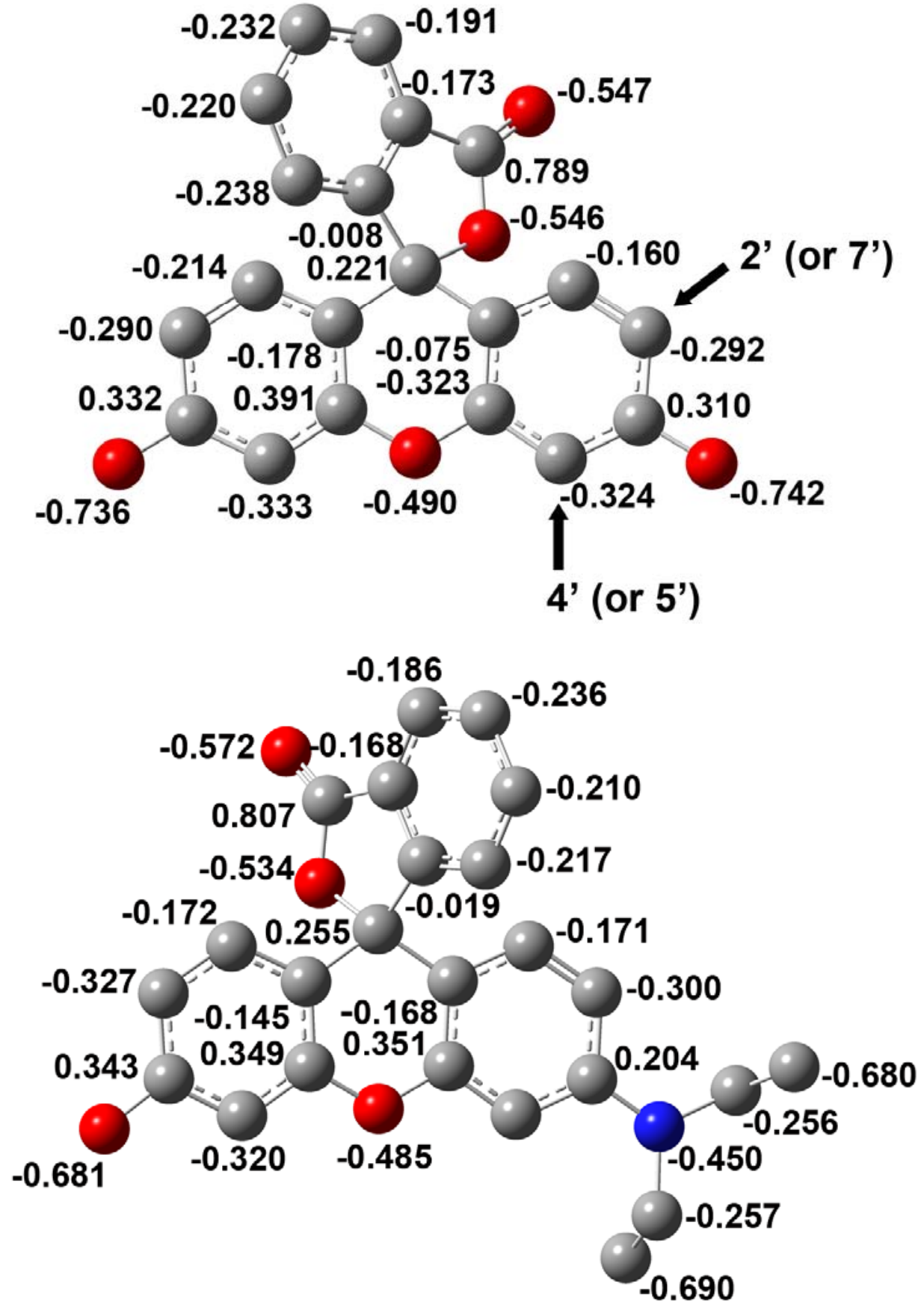

Figure S1 NPA data of the fluorescein (upper) and Rhodol (bottom). 


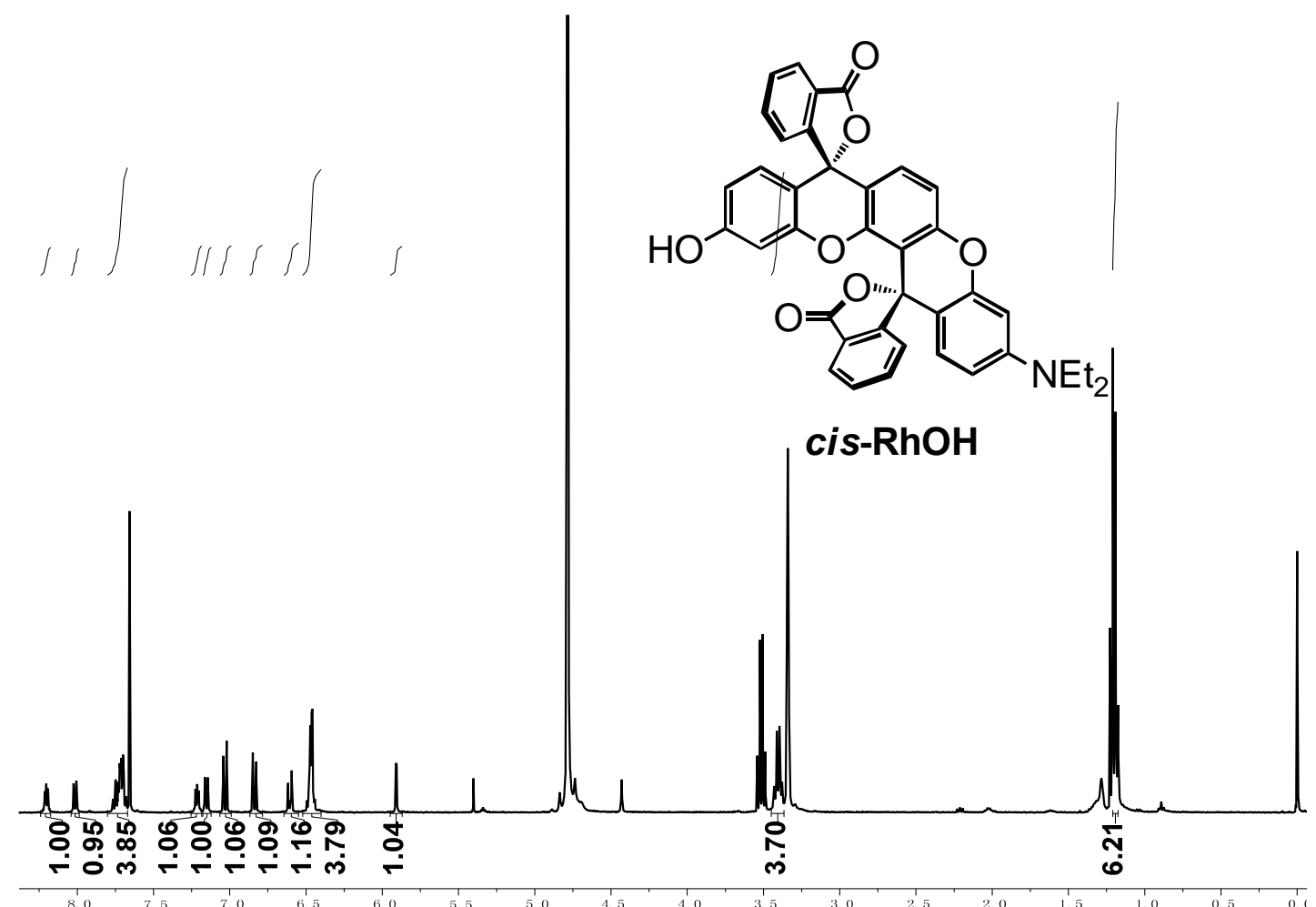

Figure S2 $\quad{ }^{1} \mathrm{H}$ NMR spectrum of cis-RhOH $\left(400 \mathrm{MHz}, \mathrm{CDCl}_{3}-\mathrm{MeOD}\right)$.

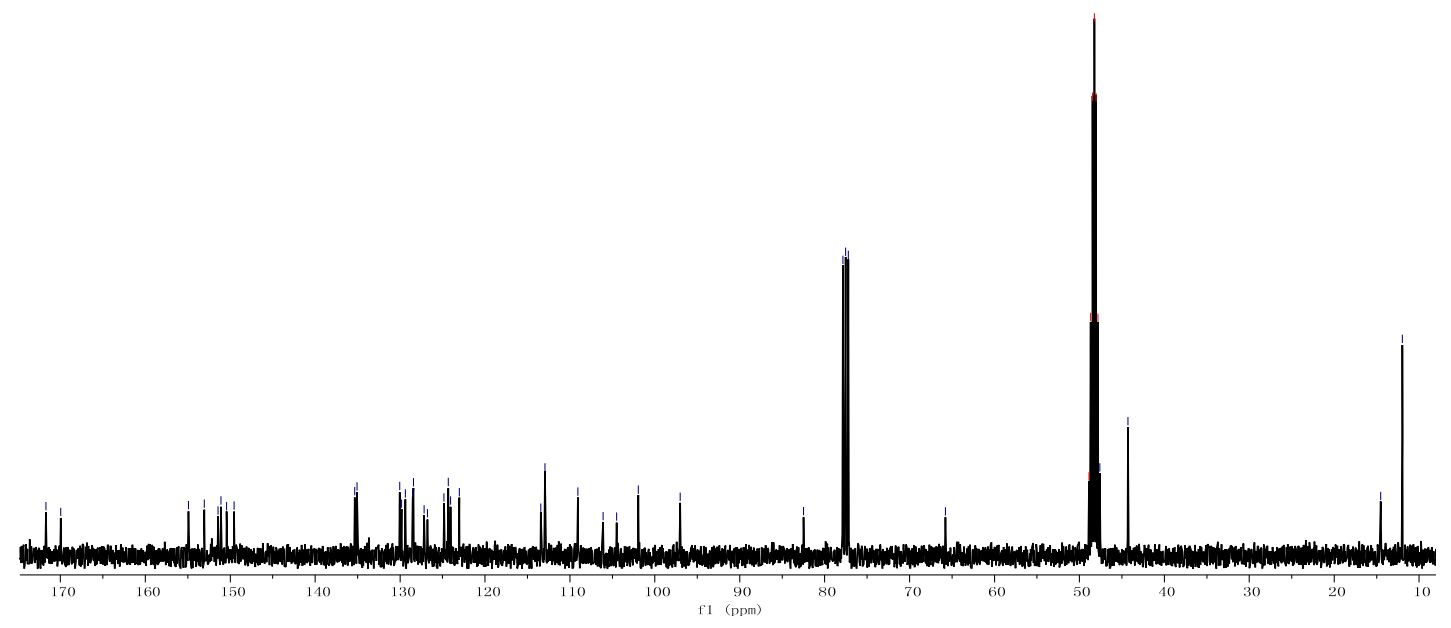

Figure S3 $\quad{ }^{13} \mathrm{C}$ NMR spectrum of cis-RhOH (400MHz, $\left.\mathrm{CDCl}_{3}-\mathrm{MeOD}\right)$. 


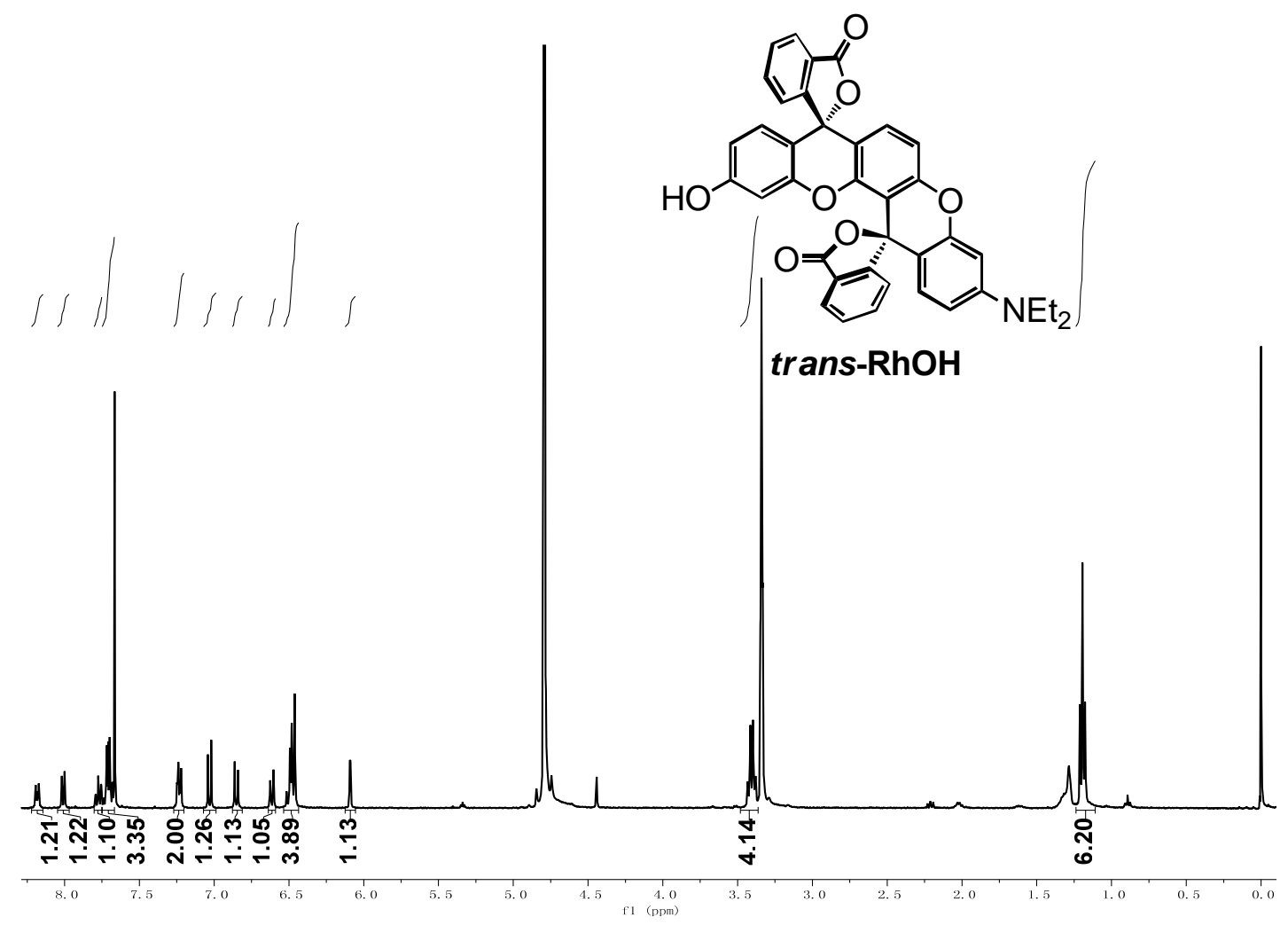

Figure S4 $\quad{ }^{1} \mathrm{H}$ NMR spectrum of trans-RhOH (400MHz, $\left.\mathrm{CDCl}_{3}-\mathrm{MeOD}\right)$

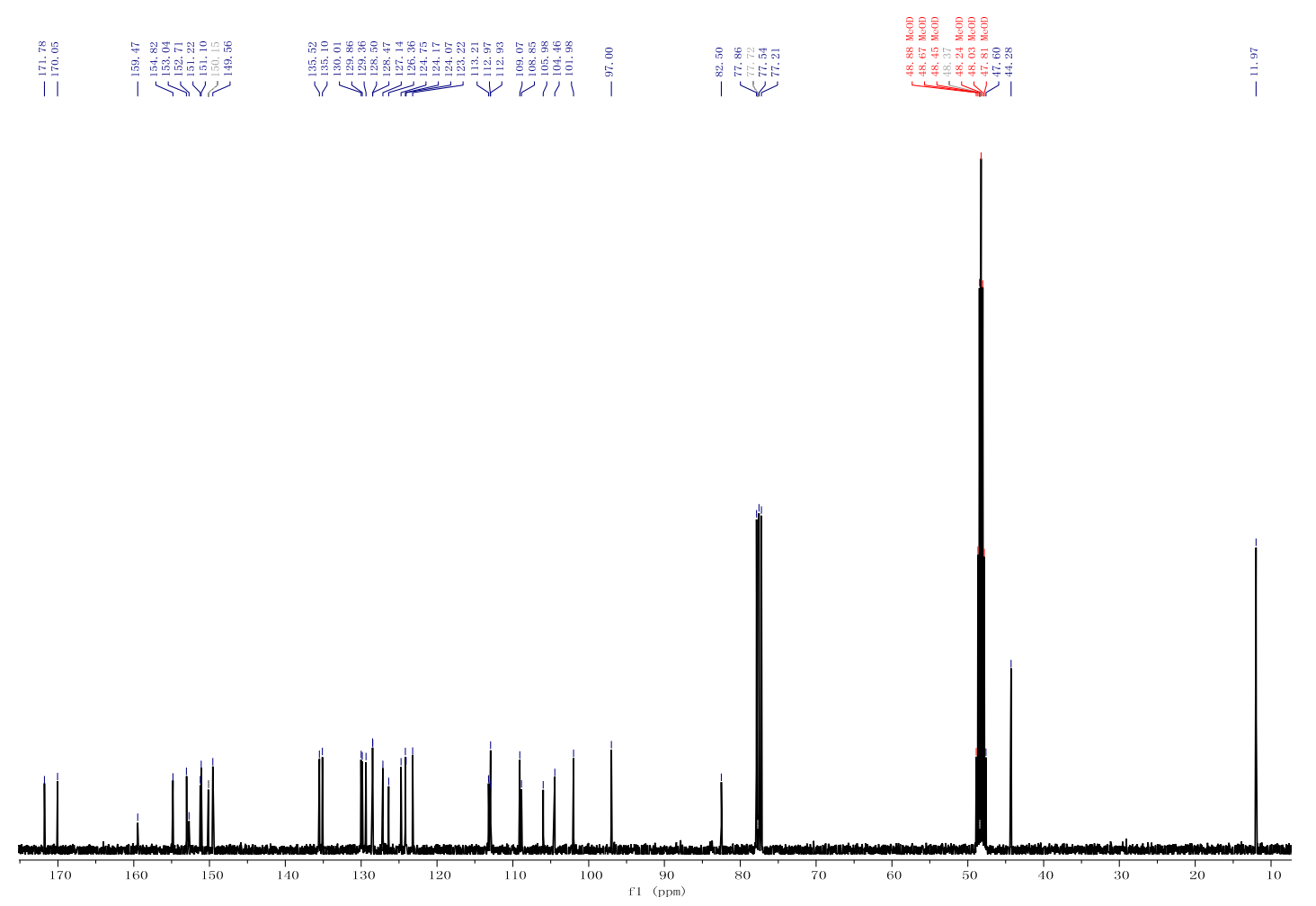

Figure S5 $\quad{ }^{13} \mathrm{C}$ NMR spectrum of trans-RhOH $\left(400 \mathrm{MHz}, \mathrm{CDCl}_{3}-\mathrm{MeOD}\right)$ 

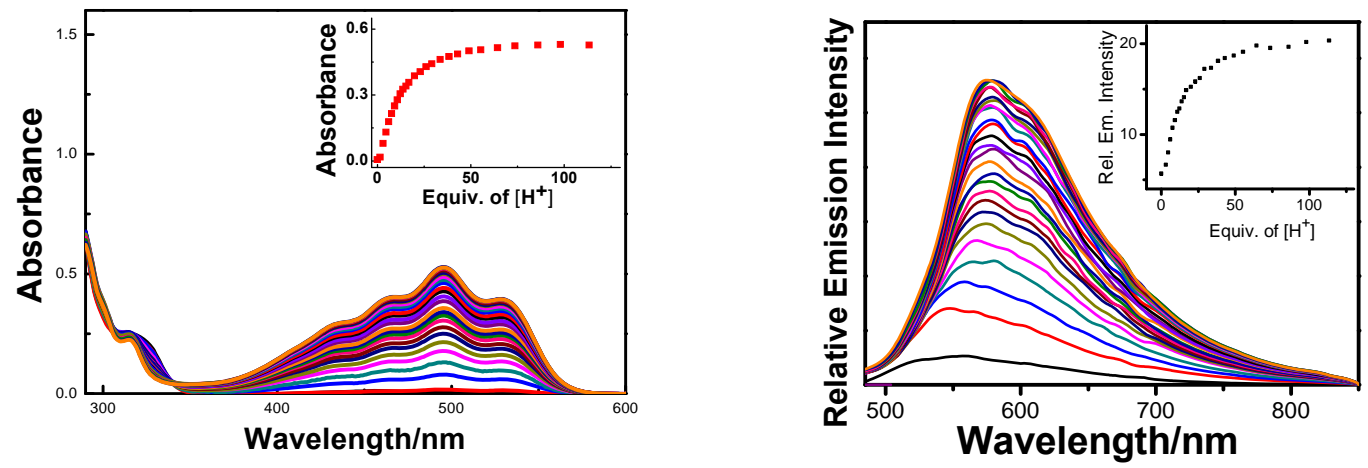

Figure S6 Absorption and emission spectral of trans-RhOH (conc. $\left.=3 \times 10^{-5} \mathrm{M}\right)$ upon addition of the $\left[\mathrm{H}^{+}\right]$in $\mathrm{MeOH}$. 

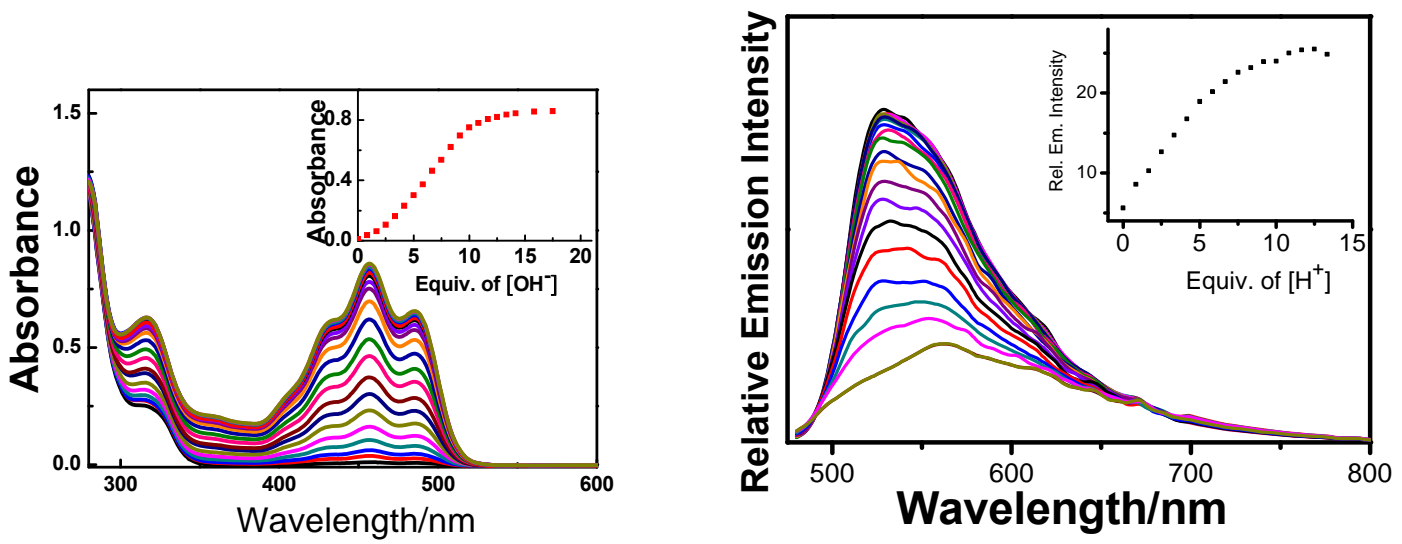

Figure S7 Absorption and emission spectral of trans-RhOH (conc. $=3 \times 10^{-5} \mathrm{M}$ ) upon addition of the $\left[\mathrm{OH}^{-}\right]$in $\mathrm{MeOH}$. 

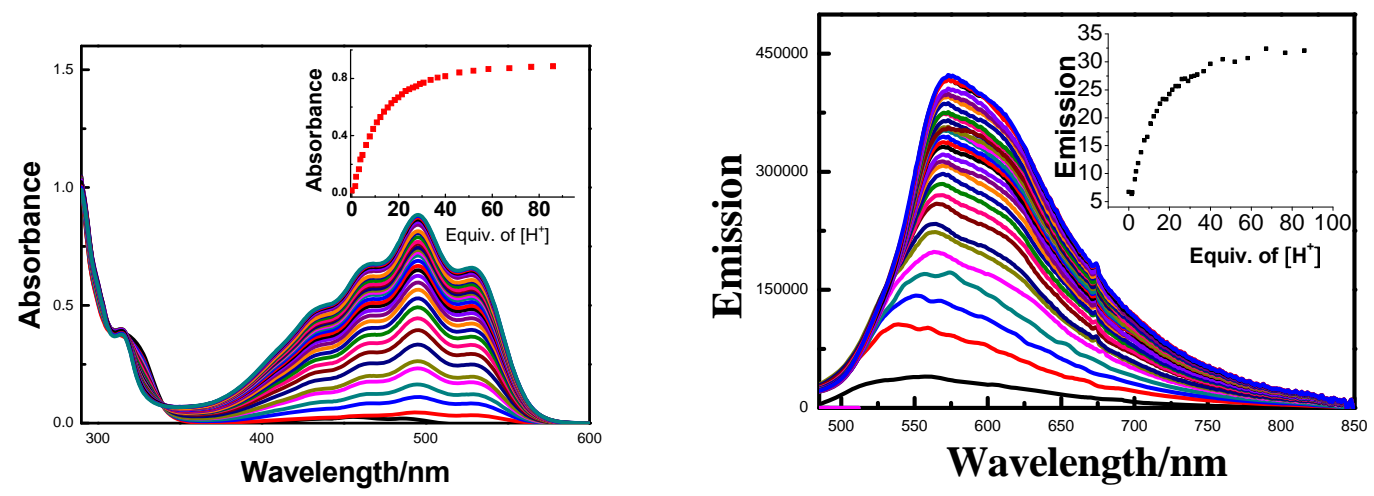

Figure S8 Absorption and emission spectral of cis-RhOH (conc. $\left.=3 \times 10^{-5} \mathrm{M}\right)$ upon addition of the $\left[\mathrm{H}^{+}\right]$in $\mathrm{MeOH}$. 

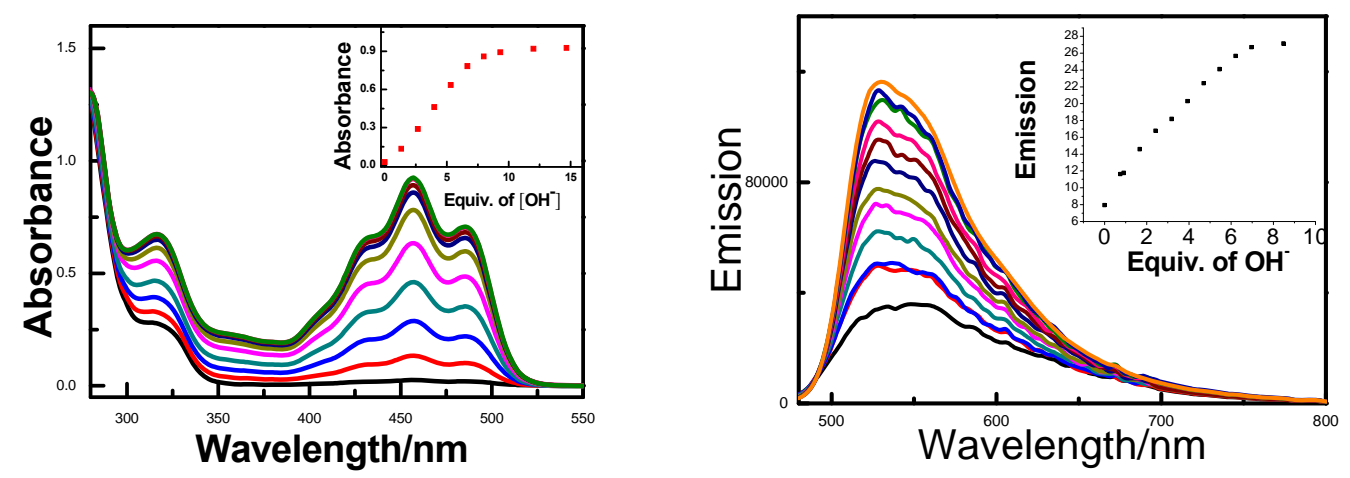

Figure S9 Absorption and emission spectral of cis-RhOH (conc. $\left.=3 \times 10^{-5} \mathrm{M}\right)$ upon addition of the $\left[\mathrm{OH}^{-}\right]$in $\mathrm{MeOH}$. 


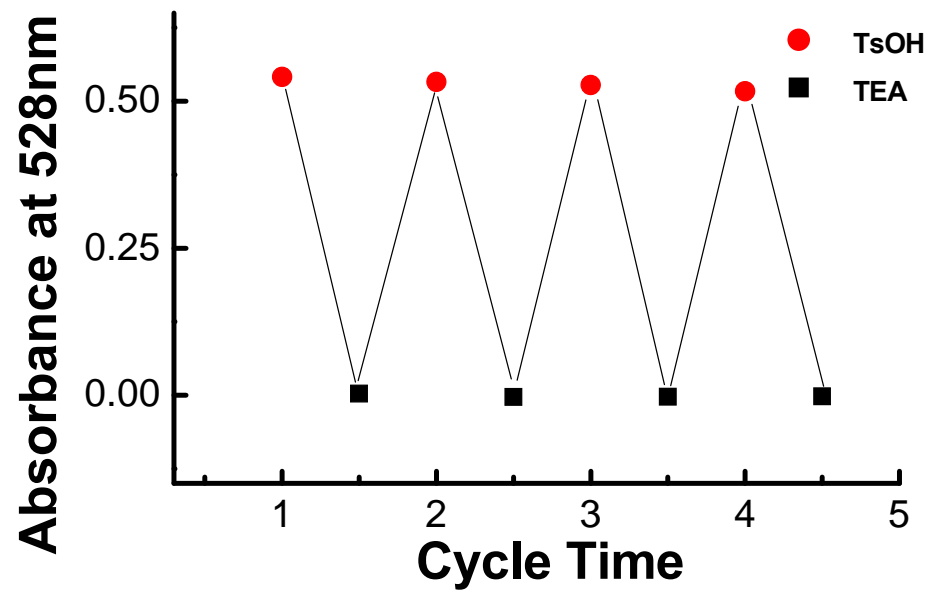

Figure S10 Reversibility of cis-RhOH (conc. $\left.=10^{-5} \mathrm{M}\right)$ in $\mathrm{MeOH}$ upon addition of TsOH $(0.1 \mathrm{M})$ and TEA $(0.1 \mathrm{M})$. 


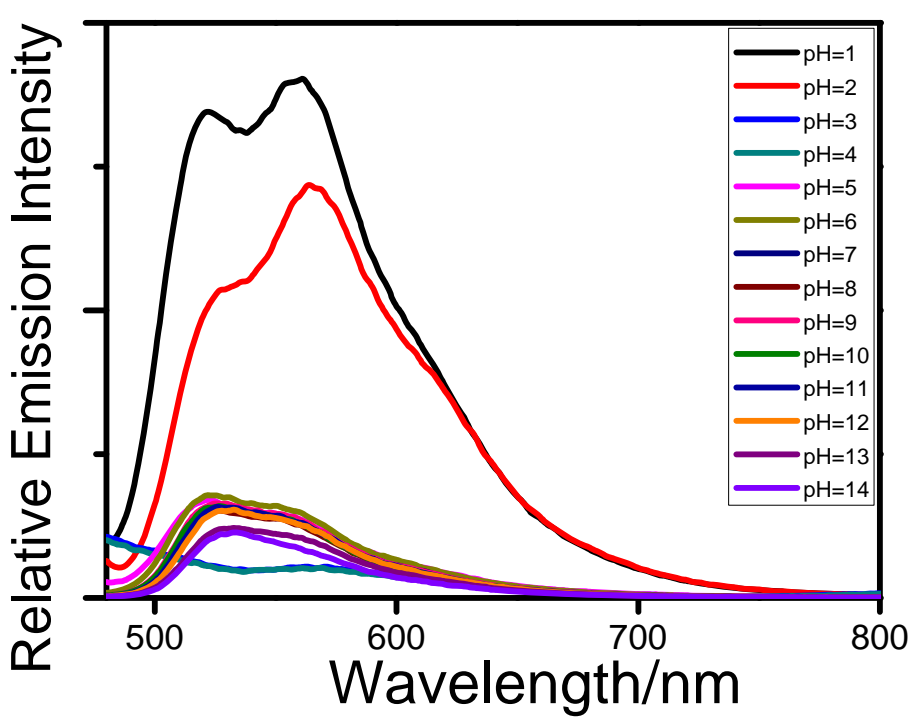

Figure S11 Emission spectra of trans-RhOH $(50 \mu \mathrm{M})$ in $\mathrm{MeOH}$ : Buffer solution $(1: 1, \mathrm{v} / \mathrm{v})$ (Different buffer solutions were prepared by using $50 \mathrm{mM}$ of potassium hydrogen phthalate (for $\mathrm{pH}$ 1-5 buffer), $25 \mathrm{mM}$ of potassium dihydrogen phosphate (for $\mathrm{pH} 6-8$ buffer), $10 \mathrm{mM}$ of sodium tetraborate (for $\mathrm{pH}$ 9-10 buffer), and 50mM of sodium bicarbonate (for $\mathrm{pH}$ 11-14 buffer). The $\mathrm{pH}$ was adjusted by adding $0.1 \mathrm{M}$ of $\mathrm{NaOH}$ or $0.1 \mathrm{M}$ of $\mathrm{HCl}$ solutions. 

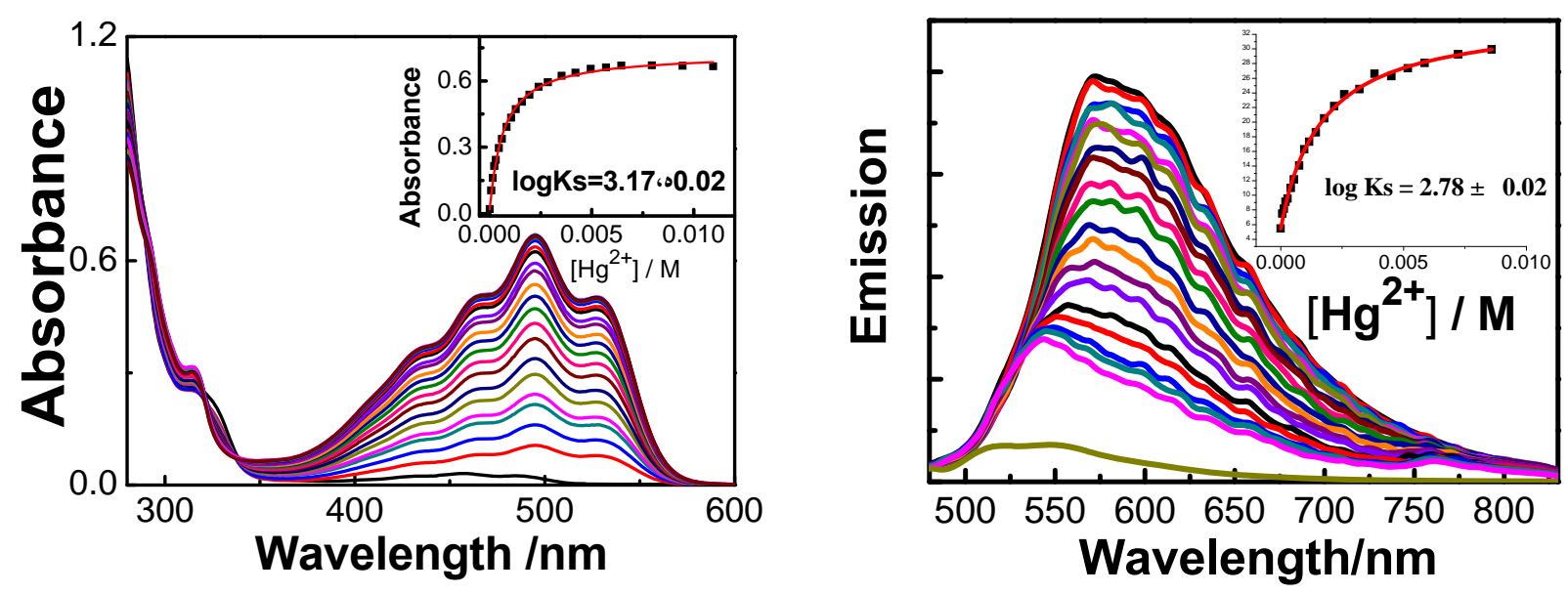

Figure S12 Absorption (left) and emission (right) spectral changes of trans-RhOH (conc. $=3 \times$ $\left.10^{-5} \mathrm{M}\right)$ upon addition of the $\left[\mathrm{Hg}^{2+}\right]\left(\right.$ conc. $\left.=4 \times 10^{-2} \mathrm{M}\right)$ in $\mathrm{MeOH}$. Insets show the plots of the absorbance at $495 \mathrm{~nm}$ or emission intensity at $575 \mathrm{~nm}$ as a function of the concentration of $\mathrm{Hg}^{2+}$ with a theoretical fit. 


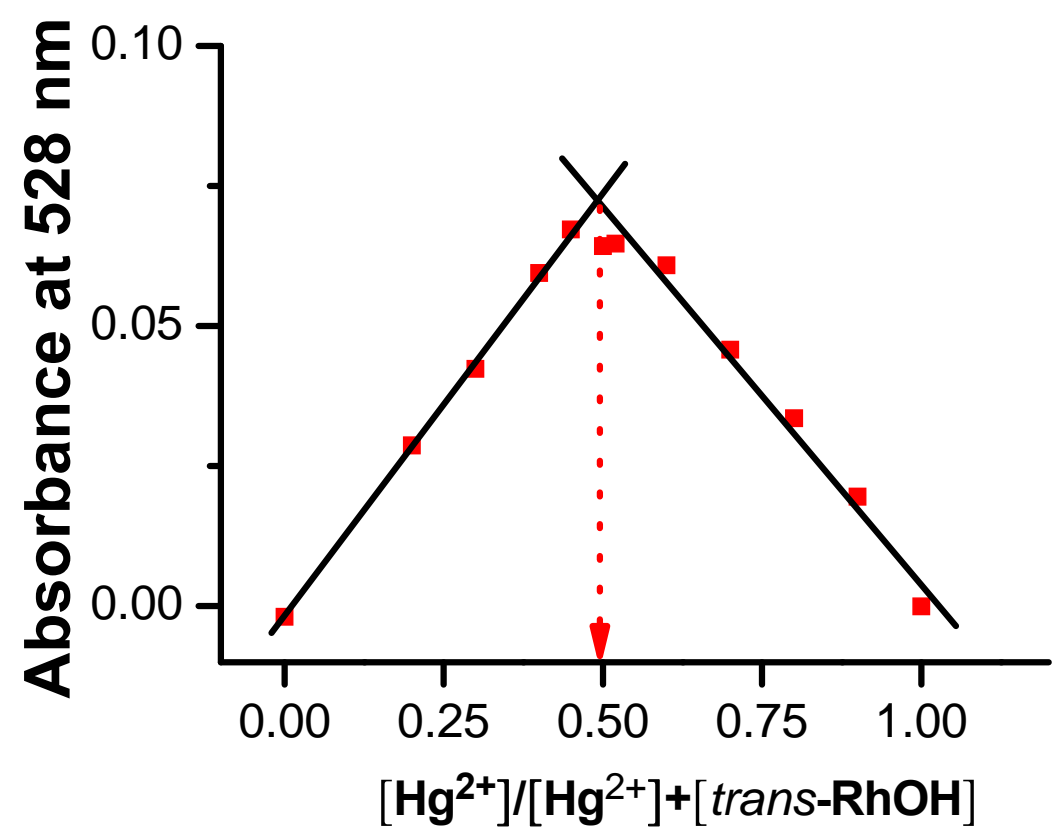

Figure S13 Job plots of trans-RhOH and $\mathrm{Hg}^{2+}$. The total concentration of trans-RhOH and $\mathrm{Hg}^{2+}$ was kept constant at $10^{-4} \mathrm{M}$. 
RhOH+Hg \#26 RT: 0.11 AV: 1 NL: $4.23 E 8$
T: FTMS + p ESI Full ms [200.00-1500.00]
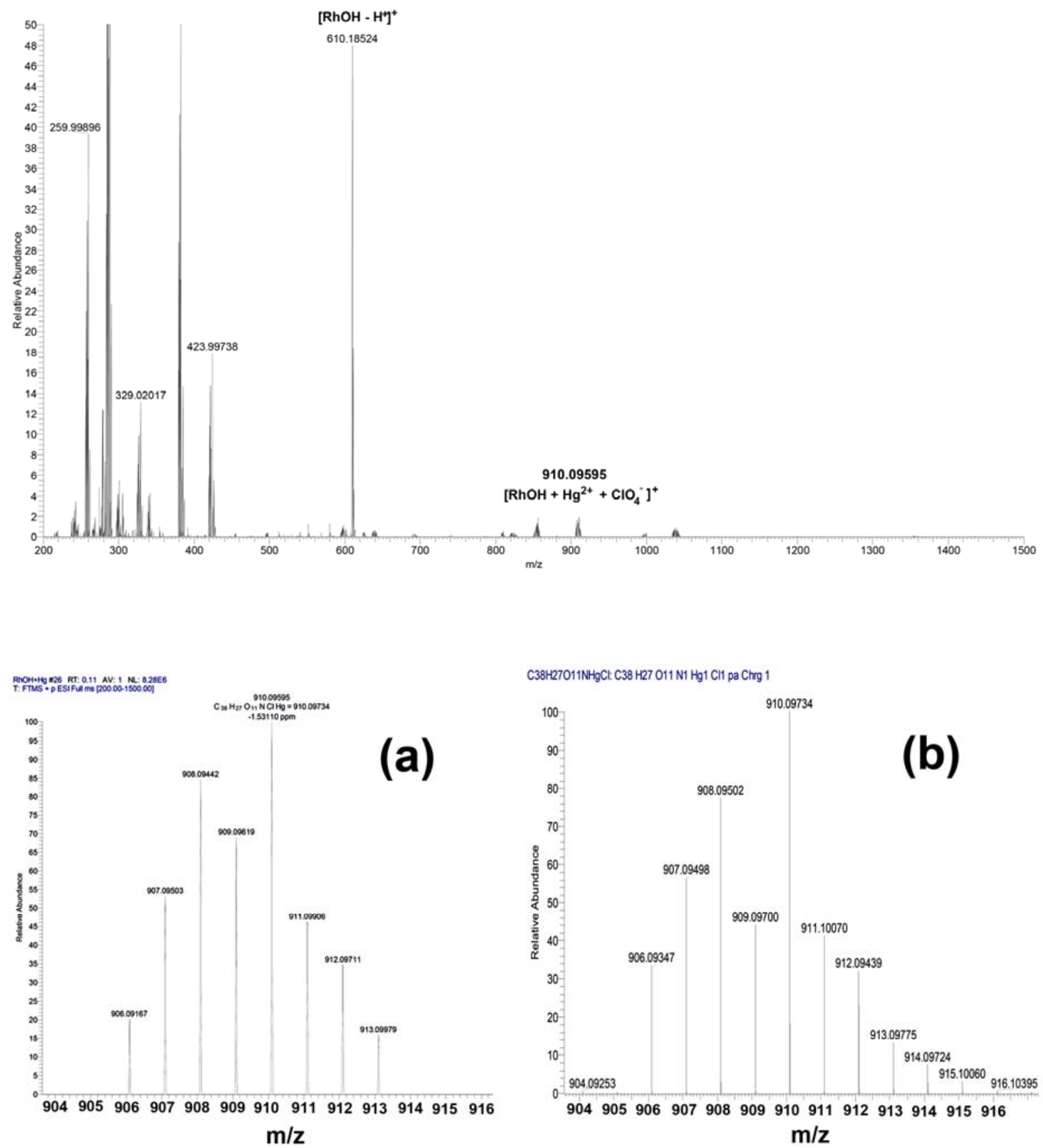

Figure S14 (Upper) HRMS spectrum of trans-RhOH with 1 equivalent of $\mathrm{Hg}\left(\mathrm{ClO}_{4}\right)_{2}$. (Bottom)

Expanded region (a) for the peak of $\mathrm{m} / \mathrm{z}=910$ and the simulated isotope pattern (b) for $\left[\text { trans-RhOH }+\mathrm{Hg}^{2+}+\mathrm{ClO}_{4}{ }^{-}\right]^{+}$. 


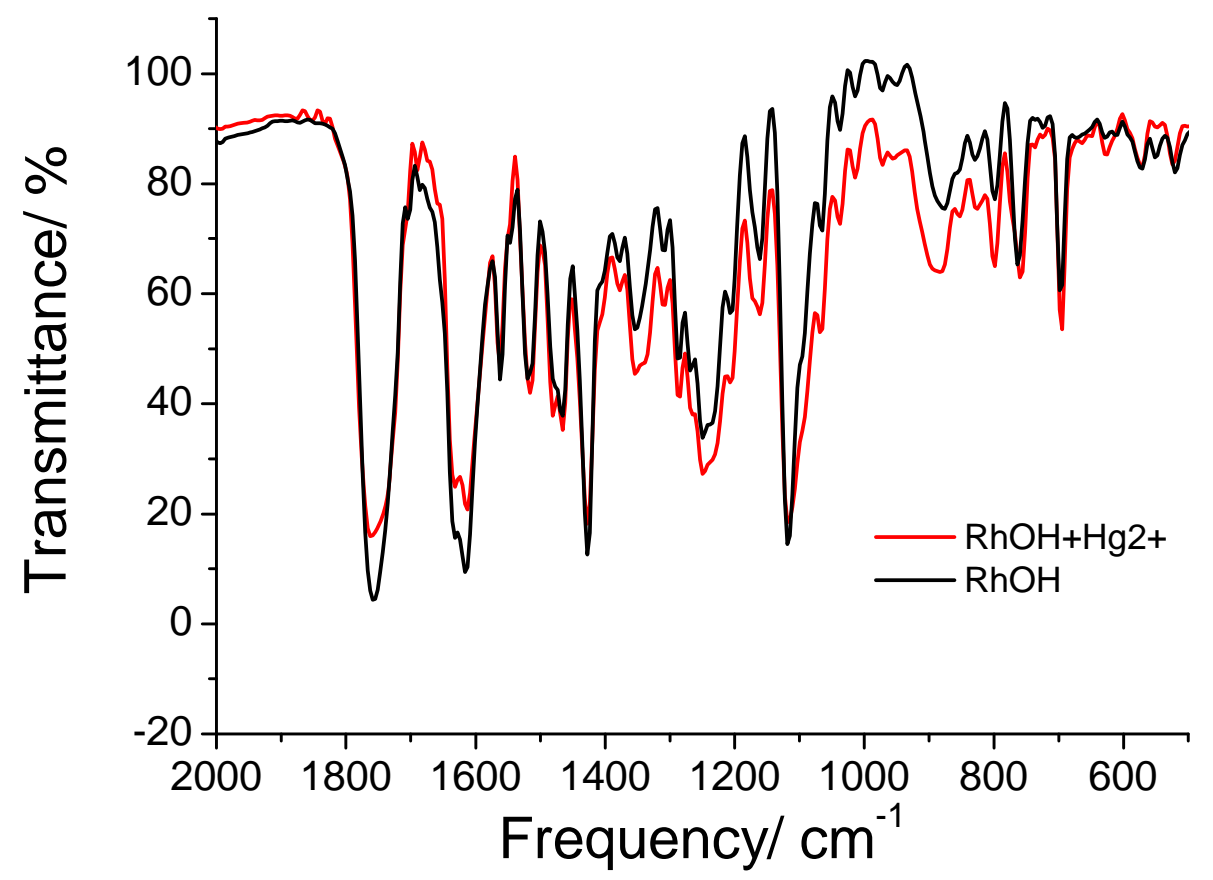

Figure S15 Solid state IR spectra of trans-RhOH and trans- $\mathbf{R h O H}+\mathrm{Hg}^{2+}$. 


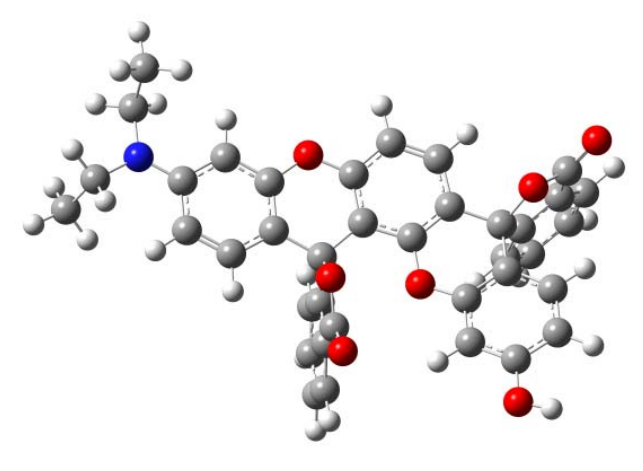

Two-closed

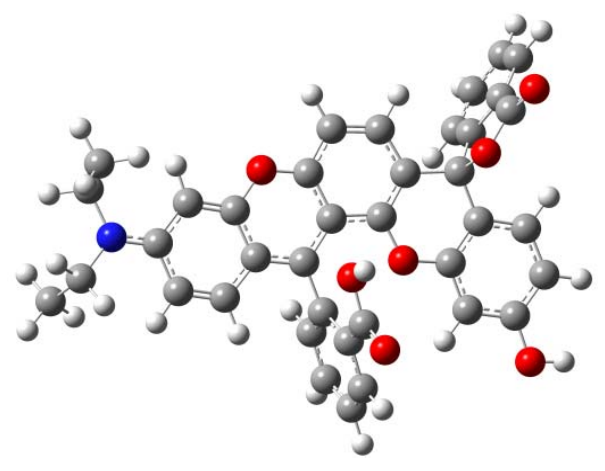

$-\mathrm{NEt}_{2}$ opened

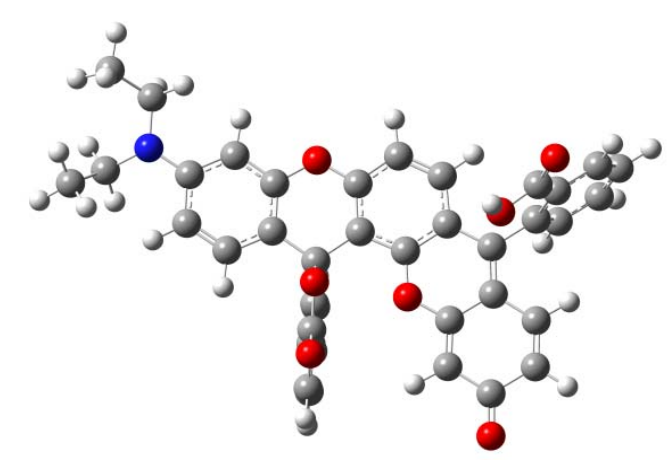

$-\mathrm{OH}$ opened

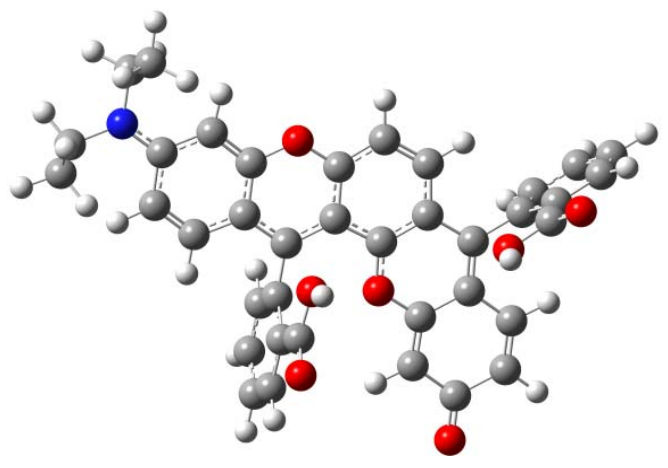

Two-opened

Figure S16 The geometry optimized structures of four compounds (Two-closed, -OH opened,

-NEt ${ }_{2}$ opened and Two-opened) calculated at B3LYP/6-31G(d) level. 
Table S1 Electronic transition data obtained by TD-DFT for four compounds

\begin{tabular}{|c|c|c|c|c|c|}
\hline Compound & Electron transition & $\begin{array}{l}\text { Main transition configuration } \\
\text { (CI coeff })\end{array}$ & $\begin{array}{c}\text { Excitation energy } \\
(\mathrm{eV})\end{array}$ & Calculated wavelength (nm) & $\begin{array}{c}\text { Oscillator strength } \\
\qquad f\end{array}$ \\
\hline \multirow[t]{2}{*}{ Cis-two-closed } & \multirow[t]{2}{*}{$\mathrm{S}_{0}-\mathrm{S}_{15}$} & HOMO-2 $\rightarrow$ LUMO+3 (0.47) & \multirow[t]{2}{*}{4.70} & \multirow[t]{2}{*}{264.06} & \multirow[t]{2}{*}{0.1704} \\
\hline & & $\mathrm{HOMO} \rightarrow$ LUMO LUMO+5 (0.22) & & & \\
\hline \multirow[t]{2}{*}{ Cis-OH-opened } & \multirow[t]{2}{*}{$\mathrm{S}_{0}-\mathrm{S}_{3}$} & HOMO $\rightarrow$ LUMO (0.49) & \multirow[t]{2}{*}{2.92} & \multirow[t]{2}{*}{425.07} & \multirow[t]{2}{*}{0.3017} \\
\hline & & HOMO-4 $\rightarrow$ LUMO & & & \\
\hline \multirow[t]{2}{*}{ Cis-NR ${ }_{2}$-opened } & \multirow[t]{2}{*}{$\mathrm{S}_{0}-\mathrm{S}_{3}$} & HOMO-2 $\rightarrow$ LUMO $(0.66)$ & \multirow[t]{2}{*}{2.81} & \multirow[t]{2}{*}{440.61} & \multirow[t]{2}{*}{0.4978} \\
\hline & & HOMO-6 $\rightarrow$ LUMO(0.16) & & & \\
\hline \multirow[t]{2}{*}{ Cis-two-opened } & \multirow[t]{2}{*}{$\mathrm{S}_{0}-\mathrm{S}_{4}$} & HOMO-2 $\rightarrow$ LUMO $(0.65)$ & \multirow[t]{2}{*}{2.72} & \multirow[t]{2}{*}{456.42} & \multirow[t]{2}{*}{0.3862} \\
\hline & & HOMO-3 $\rightarrow$ LUMO $(0.21)$ & & & \\
\hline
\end{tabular}

